УДК 373.3.011.3-051:[373.3.035:172.15]
DOI:

Олександр Кошелєв, кандидат педагогічних наук, доиент кафедри природничо-математичних наук та інформатики в початковій освіті ДВНЗ “Донбаський державний педагогічний університет”

Олена Бескорса, кандидат педагогічних наук, дочент кафедри теорії і практики початкової освіти ДВНЗ “Донбаський державний педагогічний університет”

\title{
РОЛЬ УЧИТЕЛЯ У ФОРМУВАННІ ГРОМАДЯНСЬКОЇ КОМПЕТЕНТНОСТІ УЧНІВ ПОЧАТКОВОЇ ШКОЛИ
}

У статті представлено докладний аналіз сутності поняття “громадянська компетентність", обтрунтованого аналізом вітчизняних та зарубіжних наукових джерел та рекомендаціями $і$ документів Ради Свропи. Зазначено, що громадянську компетентність визначено як одну із десяти ключових компетентностей концепџї̈ Нової украӥнської школи. Доведено, щчо зміст формування громадянської компетентності в початковій школі полягає в формуванні знань і вмінь учнів про державу, рідний край, особливості спілкування в родині, у суспільстві, права і відповідальність громадянина. Автори наголошують на визначальній ролі вчителя у формуванні громадянської компетентності учнів.

Ключові слова: громадянська компетентність; учні початкової школи; концепція "Нова українська школа”, демократичне суспільство; громадська відповідальність; функиї педагогічної діяльності; особистісні якості вчителя.

Jim. 10.

Oleksandr Koshelyev, Ph.D.(Pedagogy), Associate Professor of the Natural and Mathematical Studies and Computer Studies in Primary Education Department SHEI "Donbas State Pedagogical University" Olena Beskorsa, Ph.D.(Pedagogy), Associate Professor of the Theory and Practice of Primary Education Department SHEI "Donbas State Pedagogical University"

\section{TEACHER'S ROLE IN DEVELOPING CIVIC COMPETENCE OF PRIMARY SCHOOL STUDENTS}

The article presents the detailed analysis of the essence of concept "civic competence" that is substantiated by studying national and foreign scientific sources, as well as by recommendations and documents of European Council. It is noted that civic competence is determined as one of the key competences of the Concept "New Ukrainian School". It is generalized that civic competence is an integrated characteristic of a personality that implies the development of a certain level of the readiness to participate in social life and to be responsible for doing different types of activities. The constituents of the civic competence are the value, knowledge and activity components. The content of developing civic competence at primary school is specified. It is claimed to provide students with knowledge and skills about their motherland, native region, the nature of communication in a family, society, as well as about rights and responsibilities of citizens. The authors emphasize the teacher's dominant role while developing the students' civic competence. It is proved that in the educational process of primary school the teacher solves a number of complicated tasks, redesigning the functions of his/her professional activities. The essential functions are proved to be organizational, project, communicative, health-preserving ones, the function of pedagogical aid and support etc. The authors pay the special attention to the description of organizational and communicative functions, as the process of developing the students' communicative skills take place at this age. It is pointed out that the success of educational influence, which is aimed at developing the primary school students' civic competence, depends upon the number of methods and techniques that the teacher uses. The authors define the set of personal qualities that the teacher needs in everyday communication with students for effective development of civic competence.

Keywords: civic competence; primary school students; Concept "New Ukrainian School"; democratic society; civic responsibility; functions of pedagogical activities; teacher's personal qualities.

П остановка проблеми у загальному вигляді та її зв'язок із важливими науковими чи практичними завданнями. Сьогодні в Україні відбуваються процеси становлення громадянського суспільства. Головними орієнтирами становлення громадянського суспільства є рекомендації і документи Ради Свропи (Citizenship Education at School in Europe - 2017; 


\section{РОЛЬ УЧИТЕЛЯ У ФОРМУВАННІ ГРОМАДЯНСЬКОӤ КОМПЕТЕНТНОСТІ УЧНІВ ПОЧАТКОВОЇ ШКОЛИ}

Recommendation of the Committee of Ministers to Member States on the Council of Europe Charter on Education for Democratic Citizenship and Human Rights Education; Competences for Democratic Culture - Living Together as Equals in Culturally Diverse Democratic Societies; Citizenship Education in Europe) [8], в яких наголошено на визначальній ролі процесів дотримання прав людини та формування демократичних цінностей у розбудові сучасного суспільства.

У проекті Ради Європи “Освіта для демократичного громадянства" (Education For Democratic Citizenship) зазначено, що для активної участі громадян у процесах демократизації суспільства необхідно забезпечити їх знаннями щодо прав і обов'язків людини, норм поведінки в суспільстві та морально-етичних цінностей [9]. Незважаючи на активну діяльність Ради Свропи та запровадження цілої низки програм та проектів для розвитку громадянської освіти, не всі держави, зокрема і Україна, виявляють готовність створити громадянське суспільство і жити в умовах демократії, тому важливе завдання сьогодні покладається на заклади освіти, які мають створити умови для становлення моральної громадянської позиції, формування громадянської компетентності та отримання досвіду соціально корисної діяльності.

Важлива роль у процесі формування громадянської компетентності належить учителю, адже він безпосередньо впливає на виховання й навчання молодого покоління, передання та примноження духовних надбань рідної культури, формування культури спілкування в суспільстві, розвиток духовності, фізичної досконалості, моральної, естетичної, правової, трудової та екологічної культури.

Аналіз основних досліджень і публікацій, в яких започатковано розв'язання даної проблеми і на які спирається автор. У травні 2018 року Європейський парламент і Рада Європейського Союзу затвердили Рамкову програму оновлених ключових компетентностей для навчання впродовж життя (Council Recommendation of 22 May 2018 on Key Competences For Lifelong Learning). В оновленому переліку компетентностей наголошено на необхідності формування громадянської компетентності через освіту, а громадянське суспільство $є$ платформою для розкриття творчих можливостей особистості, а також забезпечення iii стійкості та здатності адаптуватися до змін на ринку праці, спричинених розвитком технологій у всіх сферах життя.

Поняття громадянської компетентності розглядається в низці наукових праць вітчизняних (М. Боришевський, Ю. Завалевський, А. Капська, О. Сухомлинська, I. Тараненко, К. Чорна та ін.) та зарубіжних дослідників (G. Almond, B. Hoskins, Ch. Merriam, G. Whitmarsh). Вітчизняні науковці докладно вивчають роль громадянської компетентності в становленні фахівців різних сфер діяльності: майбутніх офіцерів (А. Бухун), медиків (Л. Ковальчук, Г. Побережна, Т. Федик, М. ШінкарукДиковицька), педагогів (О. Майданик, В. Піддячий), держслужбовців (В. Щегорцова).

О. Пометун, О Шестопалюк докладно визначають зміст і структуру, а також умови розвитку громадянської компетентності сучасної молоді, яка забезпечує формування людинигромадянина, обізнаного зі своїми громадянським правами і свободами, здатного виконувати громадянські обов'язки та виявляти відповідальність. А. Гаязов, І. Доліна, В. Журова, О. Кіян присвятили свої праці вивченню педагогічних умов формування громадянської компетентності учнів закладів загальної середньої освіти. Т. Ремех дослідила сутність і структуру громадянської компетентності молодших школярів згідно з оновленням нормативної бази та стандартів освіти. Але, незважаючи на низку наукових досліджень та літературних джерел із проблеми формування громадянської компетентності, поза увагою науковців залишається визначення ролі сучасного вчителя в формуванні громадянської компетентності учнів початкової школи [6].

Формування мети статті (постановка завдання). Метою статті є визначення сутності громадянської компетентності молодшого школяра та опис ролі вчителя в процесі іiі формування.

Виклад основного матеріалу дослідження 3 повним обгрунування отриманих наукових результатів. Центральне місце в системі освіти займають заклади загальної середньої освіти, здійснюючи вплив на формування особистості, iї громадянської позиції та моральних якостей. Відповідно до концепції “Нова українська школа" соціальна та громадянська компетентність є однією із ключових компетентностей учнів [3]. Визначення поняття громадянської компетентності, на думку О. Пометун, має базуватися на загальних засадах компетентнісного підходу в освіті, сутність якого полягає не в транслюванні знань і вмінь, а в засвоєнні знань, формуванні цінностей і ставлення, набутті досвіду [5]. У Державному стандарті початкової загальної освіти компетентність визначено як “інтегровану здатність особистості, яка складається зі знань, досвіду, цінностей і 


\section{РОЛЬ УЧИТЕЛЯ У ФОРМУВАННІ ГРОМАДЯНСЬКОЇ КОМПЕТЕНТНОСТІ УЧНІВ ПОЧАТКОВОЇ ШКОЛИ}

ставлення, що можуть цілісно реалізовуватися на практиці” [2].

Із огляду на сутність компетентнісного підходу, вітчизняні науковці (О. Пометун, Т. Ремех, О. Сухомлинська, О. Шестопалюк) визначають громадянську компетентність як сукупність знань, умінь і навичок, ставлень, переконань, емоційно-ціннісних орієнтацій учнів, які допомагають їм усвідомити своє місце і роль у суспільстві, нести відповідальність за себе і свої дії, а також готовність реалізовувати громадянські права i обов'язки 3 метою розвитку демократичного суспільства.

Учені наголошують, що громадянська компетентність у повній мірі реалізується в реальних життєвих ситуація і іï формування не може бути ізольованим від умов конкретної діяльності. Таке трактування громадянської компетентності не суперечить визначенням, які представлено в зарубіжній науковій літературі. Так, M. Branson стверджує, що головна сутність процесу формування громадянської компетентності полягає в залученні громадян до відповідальної участі в суспільному житті як на місцевому, так і на національному рівні. Така участь вимагає сформованості компонентів громадянської компетентності, а саме: оволодіння знаннями, формування пізнавальних умінь, формування демократичних цінностей, орієнтацій, самореалізація особистості, вибудовування власної життєвої позиції на засадах принципів демократії тощо [7].

Вищезазначене дає нам підстави стверджувати, що громадянська компетентність $є$ інтегрованою характеристикою особистості, що передбачає сформованість певного рівня готовності до участі в суспільному житті і несення відповідальності за виконання різних видів діяльності. Складовими громадянської компетентності $є$ ціннісний, знаннєвий та діяльнісний компоненти.

У чисельних працях педагогів доведено, що формування громадянської компетентності має розпочинатися в ранньому віці. Кожен із компонентів структури громадянської компетентності реалізується через запровадження активних форм i методів навчання, що базуються на демократичному стилі взаємодії вчителя й учнів початкової школи, учнів один із одним і сприяють формуванню креативних умінь і критичного мислення. Нині головне завдання громадського виховання в початковій школі полягає в формуванні знань і вмінь учнів про державу, рідний край, особливості спілкування в родині, у суспільстві, права і відповідальність громадянина [5]. На думку науковців та вчителів методистів, найбільші можливості у реалізації завдань формування громадянської компетентності містять програми навчальних предметів "Українська мова", “Природознавство”, “Основи здоров’я”, “Я у світі”, “Математика”, “Інформатика” [1].

Кінцевим результатом формування громадянської компетентності має стати:

- сформованість громадянської ідентичності, почуття гордості за свою державу, український народ й історію країни, розуміння своєї етнічної та національної належності;

- сформованість гуманістичних і демократичних цінностей, цінностей полікультурного українського суспільства;

- шанобливе ставлення до історії та культури інших народів;

- цілісний погляд на світ у його органічній єдності й різноманітності народів;

- особиста відповідальність за свої дії на основі уявлень про моральні норми соціальної справедливості та свободи;

- розвиток етичних почуттів, що лежать в основі емоційної позитивної спрямованості на іншу людину;

- розвиток навичок співпраці як із однолітками, так і $з$ дорослими;

- розвиток умінь щодо уникнення конфліктних ситуацій [1].

Визначивши сутність поняття громадянської компетентності, вважаємо за доцільне окреслити роль учителя в цьому процесі за результатами аналізу досліджень українських та зарубіжних науковців. В освітньому процесі сучасної початкової школи вчитель вирішує низку складних завдань, головними з яких є задоволення освітніх потреб учнів, узгодження освітньої мети 3 глибинними цінностями учнів, організація освітньої діяльності через підбір форм, методів, прийомів, технологій, що сприяють ефективній реалізації освітніх, виховних та розвивальних цілей навчання. Безперечно, під час вирішення зазначених завдань учитель має перебудовувати свої професійні дії, вдосконалювати функції педагогічної діяльності, a саме: організаційну, проектувальну, комунікативну, здоров'я збережувальну, функцію педагогічної допомоги та підтримки, мобілізаційну тощо [4].

На початковому ступені навчання в учнів розвиваються комунікативні вміння, зокрема вміння спілкуватися, вести діалог, сприймати різні точки зору, поважати думки інших, знаходити консенсус, співпрацювати, що допомагає дитині адаптуватися в класному шкільному колективі та інтегруватися в суспільство. Реалізуючи організаційну та комунікаційну функцію в процесі 


\section{РОЛЬ УЧИТЕЛЯ У ФОРМУВАННІ ГРОМАДЯНСЬКОЇ КОМПЕТЕНТНОСТІ}

УЧНІВ ПОЧАТКОВОЇ ШКОЛИ

здійснення освітнього впливу на молодших школярів, важливо сформувати почуття відповідальності за виконувані завдання, готовність працювати з новим матеріалом, мати власну думку щодо обговорюваних питань. Завданням вчителя $\epsilon$ підбір навчальних матеріалів, тем для побудови діалогів та монологічних висловлювань, груп слів та стійких словосполучень, в яких утілено ключові поняття громадянської освіти. Тематика сюжетнорольових ігор має бути дібрана у такий спосіб, щоб вона не лише спонукала молодших школярів до говоріння, але й сприяла формуванню демократичних цінностей. Задачі мають стосуватися релевантних питань демократичного громадянства та прав людини, спонукати учнів до самостійного пошуку й аналізу інформації, самостійного та критичного мислення [1].

Успішність виховного впливу 3 метою формування громадянської компетентності учнів початкової школи залежить від арсеналу методів та прийомів навчання, які застосовує вчитель. Особливого значення набувають інтерактивні методи навчання, ефективність впливу яких досягається, коли враховуються психологічні особливості спілкування з учнями цього вікового періоду. Науковці наголошують на зміненні ролі вчителя, перетворенні його на фасилітатора. Учитель-фасилітатор має керуватися лише демократичним стилем спілкування з учнями, спонукати їх до взаємодії без примусу, підтримувати та надихати.

Організація інтерактивного навчання сприяє розвитку активного громадянства учнів через дію, тому що саме інтерактивні методи навчання передбачають моделювання життєвих ситуацій, виконання соціальних ролей, спільне вирішення проблем і сприяють формуванню знань, умінь, навичок, виробленню ціннісних орієнтацій, створення атмосфери співробітництва тощо.

Посилаючись на праці зарубіжних дослідників, ми можемо стверджувати, що формування громадянської компетентності відбувається в певних соціальних ситуаціях, в яких особистість виконує певні міжособистісні ролі, стаючи часткою певного суспільства, носієм культури. Так, учитель, як лідер в дитячому колективі, є зразком для наслідування та засвоєння норм і правил поведінки в соціумі. У таких умовах дослідники визначають низку особистісних якостей, необхідних учителю у щоденному спілкуванні 3 учнями для ефективного формування громадянської компетентності, а саме: чесність - справедливе поводження з учнями; відкритість - здатність дослухатися до учнів та вчитися у них; неупередженість - однакове ставлення до всіх учнів; емпатія - розглядати питання з точки зору учнів; наполегливість - протистояння упередженості й агресивній поведінці; чутливість - обережне поводження зі спірними питаннями; повага - визнання культурних та соціальних відмінностей; автентичність - готовність ділитися власними поглядами; самосвідомість - розуміння власної ідентичності; прагнення до діалогу - заохочення учнів до ведення дискусій $[9 ; 10]$.

Слід також зауважити, що важливим $є$ збереження активної громадянської позиції вчителем не лише під час здійснення професійної діяльності, а й у повсякденному життя. Це допоможе учням зрозуміти, що громадянськість не $\epsilon$ абстрактним явищем, а стосується питань реальної життєдіяльності. Наголошення на таких якостях та інтересах вимагає від учителів виконання ролі амбасадорів цінностей активного та відповідального громадянства та втілення їх у стосунках із учнями.

Висновки 3 даного дослідження i перспективи подальших розвідок у даному напрямку. Виходячи 3 вищесказаного можна зробити висновок, що формування громадянської компетентності учнів початкової школи є вимогою часу, адже вибір Україною шляху свого розвитку відповідає глобальним європейським та світовим тенденціям розвитку суспільства (глобалізації, інтеграції, розвитку ринкової економіки). Сутність громадянської компетентності полягає в засвоєнні системи знань, умінь та набутті досвіду життєдіяльності в громадянському суспільстві. Досить вагому роль у формуванні громадянської компетентності учнів відіграє вчитель. Головними функціями його педагогічної діяльності $€$ комунікативна та організаційна, реалізація яких спрямована на створення сприятливої атмосфери для здійснення взаємодії учасників освітнього процесу задля залучення їх до соціуму, формування ціннісних пріоритетів, громадської відповідальності та особистісних якостей, які $є$ визначальними для розбудови громадянського $\mathrm{i}$ демократичного суспільства.

Перспективним, на наш погляд, є подальше розроблення методичних вказівок для запровадження ефективних методів і форм навчання 3 метою формування громадянської компетентності молодших школярів, дотримуючись принципів інтеграції.

\section{ЛІТЕРАТУРА}

1. Буйдіна О., Жабенко Л., Канівець 3., Крилевець М. Методичні рекомендації щодо 
запровадження наскрізної змістової лінії “Громадянська відповідальність” у початковій школі. Київ, 2018. 26 с.

2. Державний стандарт початкової освіти. №87. (2018， 21 лютого). URL: http:// zakon5.rada.gov.ua/laws/show/87-2018-\%D0\%BF

3. Концепція "Нова українська школа": прийнята 27 жовтня 2016. URL: http://mon.gov.ua/ activity/education/zagalna-serednya/ua-sch-2016/ konczepcziya.html (дата звернення: 30.07.2019).

4. Мартиненко С.М. Діагностична діяльність майбутнього вчителя початкових класів : теорія і практика : монографія. Київ, 2008. 434 с.

5. Пометун О. I. Формування громадянської компетентності старшокласників засобами різних предметів. URL: www.civiced.org.ua (дата звернення: 03.08.2019).

6. Ремех Т. Сутність і структура громадянської компетентності учня нової української школи. Український педагогічний журнал, 2018. № 2. C. 34-41.

7. Branson M. S. Making the case for civic education: Where we stand at the end of the $20^{\text {th }}$ Century. Washington DC, 1999. URL: http:// www.civiced.org/papers/articles mb june99 (дата звернення: 08.08.2019).

8. Competences for democratic culture - Living together as equals in culturally diverse democratic societies. Strasbourg: Council of Europe. Council of Europe, 2017. Learning to live together. Council of Europe Report on the state of citizenship and human rights education in Europe. URL: https://rm.coe.int/ the-state-ofcitizenship-in-europe-e-publication/ 168072b3cd (дата звернення: 03.08.2019).

9. Council of Europe, 2010. Recommendation of the Committee of Ministers to Member States on the Council of Europe Charter on Education for Democratic Citizenship and Human Rights Education.

10. European Commission/EACEA/Eurydice. Citizenship Education at School in Europe - 2017. Eurydice Report. Luxembourg: Publications Office of the European Union, 2017.

\section{REFERENCES}

1. Buidina, O., Zhabenko, L., Kanivects, Z. \& Krylevets, M. (2018). Metodychni rekomendatsii schodo zaprovadzhennia naskriznoi zmistovoi linii "Hromadianska vidpovidalnist" u pochatkovii shkoli [Methodological recommendations for implementing cross-cutting line "Civic responsibility" in primary school”]. Kyiv, 25 p. [in Ukrainian].
2. Kontseptsiia "Nova Ukrainska shkola" [Concept "New Ukrainian school"]. (2016, October 27). Available at: http://mon.gov.ua/activity/education/ zagalna-serednya/ua-sch-2016/konczepcziya.html [in Ukrainian].

3. Derzhavnyi standart pochatkovoi osvity. No.87 (2018, 21 lyutoho). [State Standard of Primary Education. No.87 (2018, February, 21). Available at: http://mon.gov.ua/activity/education/zagalnaserednya/ua-sch-2016/konczepcziya.html (Accessed 30 Jul. 2019). [in Ukrainian].

4. Martynenko, S. M. (2008). Diagnostychna diialnist maibutnoho vchytelia pochatkovykh klasiv: teoriia $i$ praktyka : monografiia [Diadnostic activities of future primary school teacher: theory and practice: monograph]. Kyiv, 434 p. [in Ukrainian].

5. Pometun, O. I. Formuvannia hromadyanskoi kompetentnosti starshoklasnykiv zasobamy riznykh predmetiv [Developing senior school students civic competence by means of different subjects]. Available at: www.civiced.org.ua (Accessed 03 Aug. 2019). [in Ukrainian].

6. Remekh, T. (2018). Sutnist i struktura hromadyanskoi kompetentnosti uchnia novoi ukrayinskoi shkoly [Essence and structure of new Ukrainian school student competence]. Ukrainian Pedagogical Journal, Vol. 2. pp. 34-41. [in Ukrainian].

7. Branson, M. S. (1999). Making the case for civic education: Where we stand at the end of the $20^{\text {th }}$ Century. Washington DC. Available at: http:// www.civiced.org/papers/articles_mb_june 99 (Accessed 08 Aug. 2019). [in English].

8. Competences for democratic culture - Living together as equals in culturally diverse democratic societies. Strasbourg: Council of Europe. Council of Europe, 2017. Learning to live together. Council of Europe Report on the state of citizenship and human rights education in Europe. Available at: https:// rm.coe.int/the-state-ofcitizenship-in-europe-epublication/168072b3cd (Accessed 03 Aug. 2019). [in English].

9. Council of Europe (2010). Recommendation of the Committee of Ministers to Member States on the Council of Europe Charter on Education for Democratic Citizenship and Human Rights Education. [in English].

10. European Commission/EACEA/Eurydice (2017). Citizenship Education at School in Europe 2017. Eurydice Report. Luxembourg: Publications Office of the European Union. [in English].

Стаття надійшла до редакції 14.08.2019

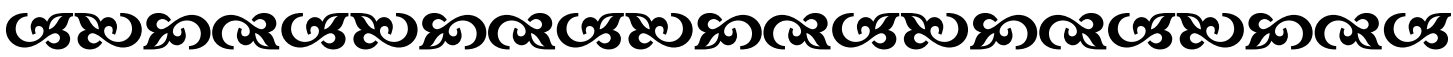

